\title{
Behaviour and growth performance of low-birth-weight piglets cross-fostered in multiparous sows with piglets of higher birth weights
}

\author{
[Comportamento e desempenho de crescimento de leitões com baixo peso ao nascer uniformizados \\ com leitões de maior peso em fêmeas suínas multíparas] \\ L.P. Souza ${ }^{1}$, H.C.C. Fries ${ }^{1}$, G. Heim ${ }^{1}$, J.E. Faccin ${ }^{1}$, L.F. Hernig ${ }^{1}$, B.T. Marimon ${ }^{1}$, \\ M.L. Bernardi ${ }^{2}$, F.P. Bortolozzo ${ }^{1}$, I. Wentz ${ }^{1}$ \\ ${ }^{1}$ Faculdade de Medicina Veterinária - Universidade Federal do Rio Grande do Sul - Porto Alegre, RS \\ ${ }^{2}$ Faculdade de Agronomia - Universidade Federal do Rio Grande do Sul - Porto Alegre, RS
}

\begin{abstract}
The aim of the study was to evaluate the behaviour, pre-weaning survival rate and growth performance of low birth weight $(\mathrm{BW})$ piglets cross-fostered with piglets of higher weights. Piglets were transferred to 60 foster sows, and divided in three groups $(\mathrm{G} ; \mathrm{n}=20)$ : $\mathrm{G} 1-12$ low BW piglets $(0.80-1.25 \mathrm{~kg})$; G2- six low BW piglets and six intermediate BW piglets $(1.40-1.60 \mathrm{~kg})$, and G3- six low BW piglets and six high BW piglets (>1.70kg). For the analysis, groups G2 and G3 were subdivided in LG2 (six G2 light piglets); IG2 (six G2 intermediate piglets), LG3 (six G3 light piglets), and HG3 (six G3 heavy piglets). Behavioural observations were carried out on days 1,2, 4 and 6 (visual direct observation) and on days 3 and 5 (video recording) after birth. The percentage of missed nursings was higher in LG3 piglets than in LG1, IG2 and HG3 piglets, on days 1 and 2. On day 4, light piglets (LG1, LG2 and LG3) missed more nursings than IG2 and HG3 piglets. On day 3, video recording showed a higher percentage of missed nursings in LG1, LG2, and LG3 piglets as compared to HG3 piglets. On day 1, the number of fights during nursing was higher in IG2 than in LG1 and LG3 piglets. Also on day 1, number of fights and percentage of piglets engaged in fights, during 15min after nursing, were higher in LG1, LG3 and HG3 than in LG2 piglets. More playful behaviours were observed on day 2 in IG2 and HG3 piglets compared to LG1, LG2 and LG3 piglets. Light piglets (LG1, LG2, and LG3) presented similar body weight on days 4, 8, 12 and 16 after birth, regardless of being mixed with piglets of higher weights or not; however, the survival rate until day 16 was most compromised in LG3 piglets compared to the other groups. Despite the lack of influence of littermates' weight on the growth of low BW piglets, their survival rate indicates that they should not be mixed with high BW piglets.
\end{abstract}

Keywords: piglet, cross-fostering, behaviour, birth weight

\section{RESUMO}

O objetivo do estudo foi avaliar o comportamento, a taxa de sobrevivência pré-desmame e o desempenho de crescimento de leitões leves ao nascer uniformizados com leitões de maior peso ao nascer (PN). Os leitões foram transferidos para 60 fêmeas e divididos em três grupos $(G ; n=20)$ : $G 1-12$ leitões de baixo $P N(0,80-1,25 \mathrm{~kg}) ; G 2$ - seis leitões de baixo PN e seis com PN intermediário (1,40-1,60kg); e G3 - seis leitões de baixo $P N$ e seis leitões pesados (>1,70kg). Para a análise, os grupos G2 e G3 foram subdivididos em LG2 (seis G2 leitões leves); IG2 (seis G2 leitões de peso intermediário); LG3 (seis G3 leitões leves) e HG3 (seis G3 leitões pesados). Observações de comportamento foram realizadas nos dias 1, 2, 4 e 6 (observações visuais diretas) e nos dias 3 e 5 (gravações) após o nascimento. A porcentagem de mamadas perdidas foi maior no grupo LG3 quando comparado aos grupos LG1, IG2 e HG3, nos dias 
1 e 2. No dia 4, leitões leves (LG1, LG2 e LG3) perderam maior número de mamadas do que os grupos IG2 e HG3. No dia 3, a gravação mostrou maior porcentagem de perda de mamadas nos grupos LG1, LG2 e LG3 do que no grupo HG3. No dia 1, o número de brigas durante a mamada foi maior nos grupos IG2 do que nos grupos LG1 e LG3. Também no dia 1, o número de brigas e porcentagem de leitões envolvidos em brigas, durante 15 minutos após a mamada, foi maior nos grupos LG1, LG3 e HG3 do que no grupo LG2. Brincadeiras foram mais observadas no dia 2 nos grupos IG2 e HG3 quando comparado aos grupos LG1, LG2 e LG3. Leitões leves (LG1, LG2 e LG3) apresentaram peso semelhante nos dias 4, 8,12 e 16 após o nascimento, independentemente de serem misturados ou não com leitões pesados. No entanto, a taxa de sobrevivência até o dia 16 foi mais comprometida nos leitões do grupo LG3 do que nos outros grupos. Apesar da falta de influência do peso das leitegadas no crescimento de leitões de baixo $P N$, a taxa de sobrevivência indicou que estes não devem ser misturados com leitões de maior PN.

Palavras-chave: leitão, equalização de leitegadas, comportamento, peso ao nascimento

\section{INTRODUCTION}

Sows have become increasingly prolific due to genetic improvement (Quiniou et al., 2002); however, this resulted in large within-litter variability in birth weight and higher numbers of low-birth-weight piglets (Milligan et al., 2001). Birth weight is a determining factor for piglet survival and growth performance (Quiniou et al., 2002). Low-birth-weight piglets, in addition to having lower energy stores, take longer to suck for the first time, making them more sensitive to cold than normal-weight piglets (Herpin et al., 2002). Colostrum must be ingested during the first hours of life in order to supply energy to the piglets, allowing body temperature regulation. Moreover, when competing with heavier piglets during teat order definition light piglets are at a disadvantage, as they usually suck in the posterior teats, which produce less milk (English and Wilkinson, 1982).

Cross-fostering is carried out to obtain more homogeneous litters in terms of number or birth weight of piglets (Neal and Irvin, 1991; Straw et al., 1998; Robert and Martineau, 2001), thereby reducing weight variation within the litter (Straw et al., 1998) and the effect of competition on the growth performance and pre-weaning mortality, mainly of light newborn piglets. When this management practice is performed up to $48 \mathrm{~h}$ after farrowing, before teat order is established, piglet growth performance and behaviour are not affected as compared to piglets exchanged after this period (Straw et al., 1998; Robert and Martineau, 2001). However, in commercial farms cross-fostering is often indiscriminately performed during the entire lactation period, resulting in delayed growth of adopted piglets.
The range of weight for piglets to be mixed in the same litter is still subject of controversy. It is believed that low-birth-weight piglets crossfostered with heavier piglets may have less chance to access the teats or to engage in effective suckling (English, 1998). On the other hand, litters with only low-birth-weight piglets may not be capable of stimulating the udder, resulting in milk ejection failure. Therefore, retaining some large piglets in the litter could improve the weight gain of low-birth-weight piglets because of the ability of heavier piglets to stimulate the teats (King et al., 1997).

The aim of this study was to evaluate the effect of mixing piglets with different birth weights on behaviour of piglets (access to the udder, missed nursings, fights, vocalisation and playful events) during the pre- and post-ejection milking phases and on piglet weight and survival until weaning.

\section{MATERIALS AND METHODS}

All experimental procedures described in this experiment were conducted under experimental license (Project number 18327) from the Institutional Animal Care and Use Committee (COMPESQ-FAVET-UFRGS).

The experiment was carried out between January and March on a commercial pig farm (2900 Agroceres PIC ${ }^{\circledR}$ sows) located in southern Brazil (Parallel 26 $6^{\circ}$.

Piglets were individually weighed before crossfostering, and allotted to treatment groups according to their weight. The piglets were crossfostered on average within $21.3 \mathrm{~h} \pm 0.32 \mathrm{~h}$ postpartum. None of the piglets remained with their biological dam and each litter contained 
equal numbers of males and females. Piglets were born from parity-two to parity-six sows and were transferred to 60 parity-two to parity-three foster sows, according to the following three groups $(\mathrm{G})$, with 20 replicates each: G1 - litters with 12 low-birth-weight piglets $(0.80-1.25 \mathrm{~kg})$, G2 - six low-birth-weight piglets mixed with six intermediate-birth-weight piglets $(1.40-1.60 \mathrm{~kg})$, and G3 - six low-birth-weight piglets mixed with six heavy-birth-weight piglets $(>1.70 \mathrm{~kg})$.

The sows were housed in cages during the gestation period and were transferred to farrowing rooms seven days before the predicted farrowing date, and were housed in individual farrowing crates. Farrowing was induced by the injection of PGF $2 \alpha$ synthetic analogue (sodium cloprostenol) when sows had, on average, 114 days of gestation. On the day of farrowing, sows were not fed, and after farrowing the amount of feed offered was gradually increased until day 4 of lactation, when ad libitum feeding was offered. Feed contained $17.5 \%$ crude protein, $1.0 \%$ lysine, and $3400 \mathrm{kcal} / \mathrm{kg} \mathrm{ME}$.

Behaviour was assessed by direct visual observation during four consecutive nursings, when piglets were 1, 2, 4 and 6 days old, crossfostering being performed on day 1. At the moment of cross-fostering, piglets were placed inside the creep box, with no contact with the sow. After $50 \mathrm{~min}$, the creep box was opened, and piglets were allowed to enter the sow area. Piglets were individually marked on their backs for easier identification. Behavioural observations started when the creep box was opened. During the first $3 \mathrm{~min}$ of observation, the number of piglets trying to reach the udder was recorded.

Visual direct behavioural observations on the piglets were performed in two episodes. The first moment corresponded to the pre-ejection and milk ejection phases, whereas the second evaluation was performed for $15 \mathrm{~min}$ after milk ejection. Milk ejection was visually defined when the movements of the jaw of piglets suckling at the udder changed from slow to rapid movements. The return to slow jaw movements characterised the beginning of post-letdown milk period (Whatson and Bertram, 1980; Wattanakul et al., 1998). The numbers of fights for teats, of piglets involved in fights, and of piglets vocalising were recorded in both observation periods. The number of playful behaviours was recorded only during the $15 \mathrm{~min}$ after milk ejection. A fight event was noted when two piglets presented aggressive physical contact, such as biting and head or shoulders knock (Petersen and Vestergaard, 1989; Erhard et al., 1997; Robert and Martineau, 2001; Deen and Bilkei, 2004). A new fight was defined when, after being distant for $3 \mathrm{~s}$, piglets engaged again in fighting (Wiegand et al., 1994; Milligan et al., 2001). Piglets were considered playing when they scampered, jumped, and tossed their heads (Donaldson et al., 2002). Piglets appeared excited but relaxed, and gave the overall impression that they were having fun (Spinka $e t$ al., 2001).

After the end of each behavioural observation (from pre-ejection until $15 \mathrm{~min}$ after milk letdown), piglets remained for 50min in the creep box until the next observation. Trios of sows including one sow from each group were observed daily. Sows were separately evaluated by a single examiner, who was previously trained. Whereas piglets of one sow were being evaluated, piglets of the other sows remained in the creep box. Piglets were kept in the creep box separated from the sow only during the four consecutive evaluated nursings. After, they were allowed to have free access to the udder of their nursing mother.

In addition to direct visual observation, video cameras were used to evaluate the number of nutritive nursing episodes and missed nursings over $24 \mathrm{~h}$ in 10 sows per group. As these evaluations started when the piglets were 2.5 and 4.5 days old and finished when they were 3.5 and 5.5 days old, respectively, these moments will be considered as D3 and D5. Nutritive nursing episodes were defined as occurring when at least $50 \%$ of the piglets gathered at the udder presented rapid suckling movements for approximately $15 \mathrm{~s}$.

Piglets were weighed at $4,8,12$, and 16 days of age using a digital weighing scale with $5 \mathrm{~g}$ accuracy. Piglets were weaned $16 \mathrm{~d}$ postfarrowing. Mortality was recorded daily.

For the analysis of the number of nutritive nursings during $24 \mathrm{~h}$ of video recording, the analysis was performed considering the three groups of sows (G1, G2 and G3). For the 
variables regarding the piglets, groups $\mathrm{G} 2$ and G3 were subdivided as follows: LG2 (G2 light piglets); IG2 (G2 intermediate-weight piglets), LG3 (G3 light piglets), and HG3 (G3 heavy piglets). Group 1 corresponded to only light piglets (LG1). All variables were analysed using litter as the experimental unit.

Percentages of missed nursings were calculated taking into account the total number of piglets that missed nursings over the total of nutritive nursing episodes each group of piglets had access to in the four consecutive evaluations. Numbers of fights for teats and of playful behaviours per piglet were expressed as the observed number of these events divided by the number of piglets of each subgroup. Vocalisations, piglets engaged in fights and in playful behaviours were expressed as percentages of piglets engaged in these behaviours over the number of piglets per subgroup within each litter.

The data were statistically analysed using Statistical Analysis System software programme, version 9.1.3 (SAS..., 2005). Differences were considered as significant at $\mathrm{P}<0.05$ or as trends for P-values between 0.05 and 0.10. All data were tested for normality with the Shapiro-Wilk test. Because they did not follow a normal distribution, the following variables were analysed by the non-parametric NPAR1WAY procedure of SAS, and groups were compared by the Kruskal-Wallis test: number of nutritive nursings of sows, percentage of piglets going towards the udder within 3 min after the creep box was opened, percentage of missed nursings, number of fights, percentage of piglets engaged in fights, percentage of piglets vocalising, number of playful behaviours, percentage of piglets engaged in playful events, and survival rate. As playful events involved only $0.31 \%$ of the piglets, on day 1 after birth, the data were not submitted to statistical analysis.

The number of nutritive nursing episodes of sows during $24 \mathrm{~h}$ was analysed with the GLM procedure and means were compared by the Tukey test. The body weight of piglets was analysed as repeated measures using the MIXED procedure with fixed effects of subgroup, period of weighing and the interaction between these two factors. LSmeans were compared by the Tukey test.

\section{RESULTS}

Piglet birth weight was similar for LG1, LG2, and LG3 piglets $(1.08 \pm 0.03 \mathrm{~kg}, 1.10 \pm 0.03 \mathrm{~kg}$ and $1.09 \pm 0.03 \mathrm{~kg}$, respectively), but were lower than those in IG2 $(1.50 \pm 0.03 \mathrm{~kg})$ and HG3 $(1.80 \pm 0.03 \mathrm{~kg})$ piglets, confirming the aim of having piglets with different initial weights.

None of the sows showed aggression towards their piglets. Through video recording for $24 \mathrm{~h}$, it was observed that, on day $3, \mathrm{G} 1$ sows tended to have a lower number $(\mathrm{P}<0.09)$ of nutritive nursing episodes than $\mathrm{G} 2$ and $\mathrm{G} 3$ sows $(22.9 \pm 1.3$ vs. $26.3 \pm 1.3$ vs. $27.6 \pm 1.3$ for $\mathrm{G} 1, \mathrm{G} 2$ and $\mathrm{G} 3$ sows, respectively). On day $5, \mathrm{G} 1$ and $\mathrm{G} 2$ sows tended to have less $(\mathrm{P}<0.07)$ nutritive nursing episodes than G3 sows $(26.6 \pm 1.2,28.1 \pm 1.3$ and $30.7 \pm 1.0$ for $\mathrm{G} 1, \mathrm{G} 2$ and $\mathrm{G} 3$ sows, respectively).

Percentages of piglets moving towards the udder did not differ $(\mathrm{P}>0.10)$ among groups on D1, D2 and D4 (overall means were $46 \%, 57 \%$ and $75 \%$, respectively). On day 6 , more LG3 and HG3 piglets moved towards the udder than LG1, LG2 and IG2 piglets (medians of 100\%, 100\%, 94\%, $73 \%$ and $79 \%$, respectively) during the first 3 min after the creep box was opened. By direct visual observation (Figure 1), it was observed that LG3 piglets missed more nursings $(\mathrm{P}<0.05)$ than LG1, IG2 and HG3 groups, and tended to miss more nursings than LG2 piglets $(\mathrm{P}<0.10)$, on day 1 . On day 2, LG2 and LG3 piglets missed more nursings than LG1, IG2 and HG3 piglets and LG1 piglets tended $(\mathrm{P}<0.10)$ to miss more nursings than IG2 and HG3 piglets. On day 4, light piglets (LG1, LG2 and LG3) missed more nursings than IG2 and HG3 piglets. On day 6, heavy piglets (HG3) missed fewer nursings than LG1, LG2 and LG3 piglets $(\mathrm{P}<0.05)$.

Video recording revealed that LG1, LG2 and LG3 piglets (medians of $5.4 \%, 5.5 \%$ and $5.2 \%$ ) missed more nursings $(\mathrm{P}<0.05)$ than $\mathrm{HG} 3$ piglets (median of $0.9 \%$ ), on day 3 . Piglets of IG2 showed an intermediate value of missed nursings (median of $3.0 \%$ ). On D5, there were no differences $(\mathrm{P}>0.05)$ in percentage of missed nursings (overall median of $0.6 \%$ ). 


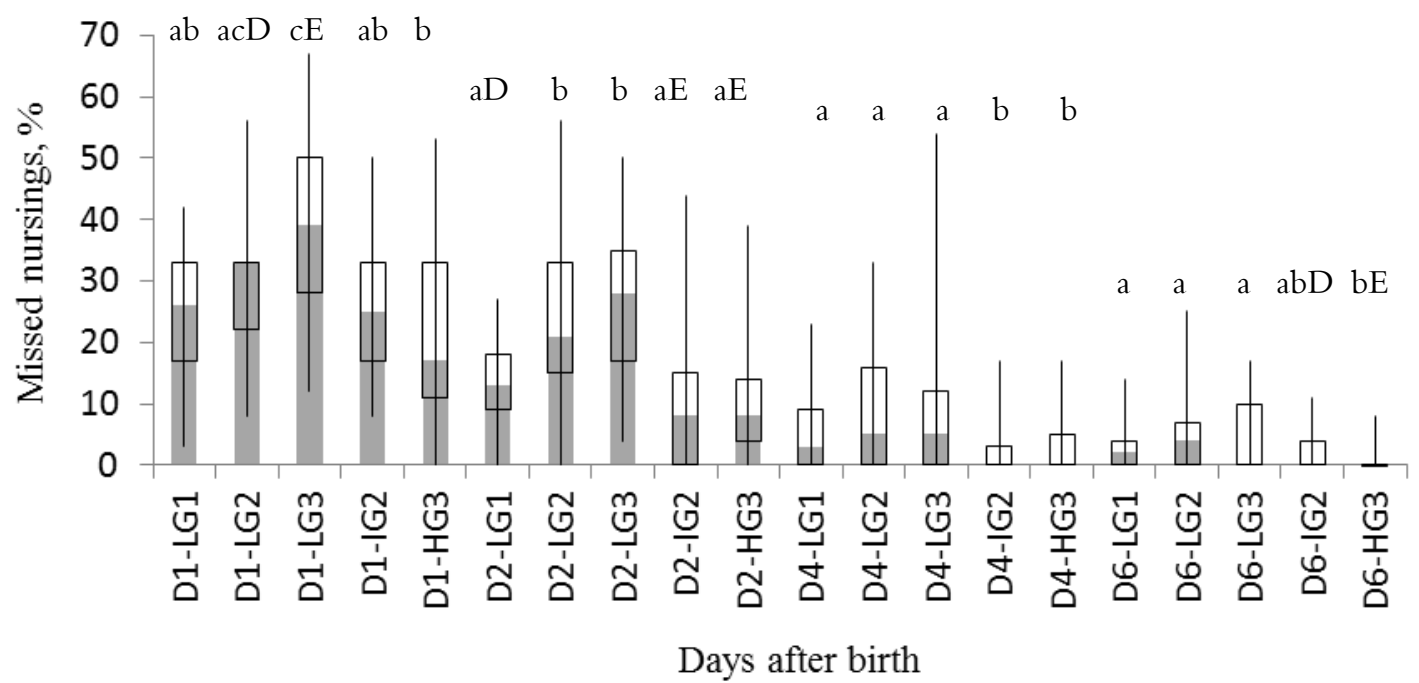

Figure 1. Percentages of missed nursings evaluated through direct visual observation on several days (D) after birth, in litters composed of piglets with similar or different birth weights. LG1= 12 low-birth-weight piglets $(0.80-1.25 \mathrm{~kg})$; LG2= six low-birth-weight piglets mixed with intermediate-birth-weight piglets; IG2= six intermediate-birth-weight piglets $(1.40-1.60 \mathrm{~kg})$ mixed with low-birth-weight piglets; LG3 = six low-birth-weight piglets mixed with high-birthweight piglets, HG3= six high-birth-weight piglets $(>1.70 \mathrm{~kg})$ mixed with low-birth-weight piglets. The boxes show minimum, first quartile, third quartile and maximum values. The superior limit of the grey bar represents the value of median. Different letters indicate statistical difference $(a, b, c ; P<0.05)$ or tendency of difference $(D, E ; P<0.10)$ among groups of piglets within each observation day.

Piglets did not fight in the sow pen before reaching the udder of their nursing mother. The observed fights occurred when piglets were already at the udder of sows and were considered as disputes for teats. The number of fights for teats and the percentage of piglets engaged in fights during nursing decreased with time (Figure 2 ). On day 1 , the number of fights for teats was higher in IG2 than in LG1 and LG3 piglets (Figure 2A). On day 2, more LG2 piglets were engaged in fights than LG1, LG3, and HG3 piglets (Figure 2B). There were no differences in the number of fights for teats on days 2, 4 and 6 , and in the percentage of piglets engaged in fights on days 1, 4 and 6 . On day 1, number of fights and percentage of piglets engaged in fights, during 15 min after nursing, were higher in LG1, LG3 and HG3 than in LG2 piglets (Figure 3). There were no differences in the number of fights and in the percentage of piglets engaged in fights on days 2,4 , and 6 .

More playful behaviour instances $(\mathrm{P}<0.05)$ were observed on day 2 in IG2 and HG3 piglets (median of 0.06 for both groups) compared to LG1, LG2 and LG3 piglets (medians of 0, 0 and
0.02, respectively). Also on day 2, more IG2 piglets were involved in playful events (median of $11 \%$ ) than LG1, LG2 and LG3 piglets (medians of $0 \%, 0 \%$ and $4.2 \%$, respectively).

There were no differences $(\mathrm{P}>0.10)$ in percentage of piglets vocalising, before and after nursing, on any observation day. Before nursing, overall medians of piglets vocalising were $10.0 \%, 7.2 \%, 4.2 \%$ and $6.2 \%$, on days $1,2,4$ and 6 , respectively. Medians corresponded to $0 \%$ on all days of observation evaluated after milk ejection.

Groups composed of low-birth-weight piglets (LG1, LG2 and LG3) had similar body weight among them $(\mathrm{P}>0.10)$ on days $4,8,12$, and 16 (Table 1), and lower body weight than intermediate-birth-weight piglets (IG2) and highbirth-weight piglets (HG3). Survival rate of LG3 piglets was lower than in LG1, IG2 and HG3 piglets, and tended to be lower than in LG2 piglets (Table 1). Survival rate of HG3 piglets was higher $(\mathrm{P}<0.05)$ than in LG1, LG2 and LG3 piglets but similar to IG2 piglets. 


\section{DISCUSSION}

The similar body weight observed among lowbirth-weight piglets, independently of the body weight of their littermates, is consistent with the observations of Milligan et al. (2001). Intermediate and high-birth-weight piglets continued to have a body weight difference relative to low-birth-weight piglets, demonstrating the importance of a high birth weight for a higher weight at weaning. Furthermore, piglets with a higher initial body weight vigorously stimulate the udder and suck all the available milk, probably ingesting larger amounts of nutrients (Fraser et al., 1979; Thompson and Fraser, 1986; Algers et al., 1991); this allowed them to grow faster than piglets with a lower initial body weight.
The impact of piglet birth weight on survival and growth performance has been shown in several studies (Milligan et al., 2002; Quiniou et al., 2002). Light piglets that die during the first days after farrowing probably failed to find and keep a functional teat (Fraser, 1990; Fraser et al., 1995). The lower survival rate of low-birth-weight piglets fostered with high-birth-weight piglets is consistent with previous reports (Milligan et al., 2001; Deen and Bilkei, 2004). Birth weight (Quiniou et al., 2002; Baxter et al., 2008) and maintenance of body temperature after birth (Tuchscherer et al., 2000) are good indicators of survival rate during the first week of life. In the present study, the higher number of missed nursings in light piglets when mixed with heavy piglets may explain their higher mortality, as milk is the source of energy for vital body processes, mainly thermoregulation.

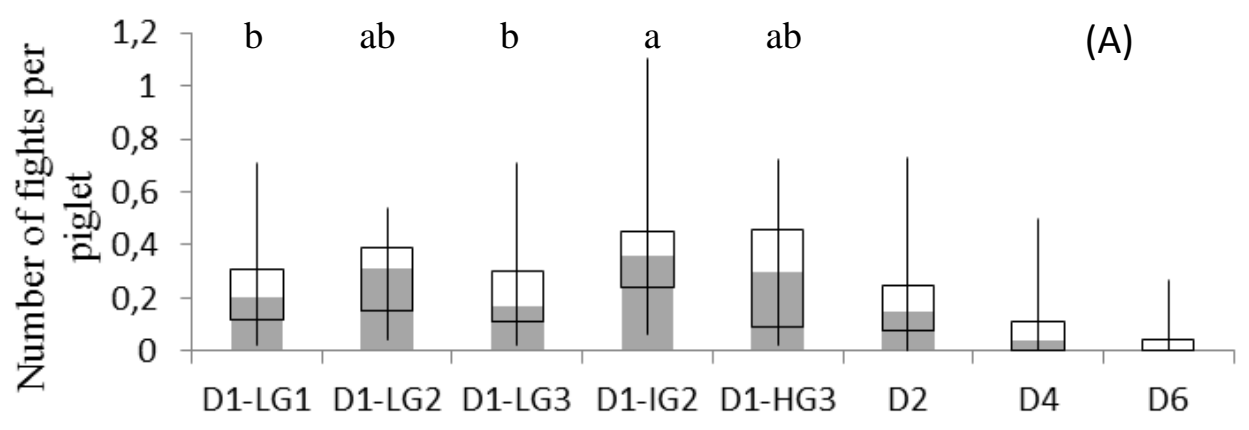

Days after birth

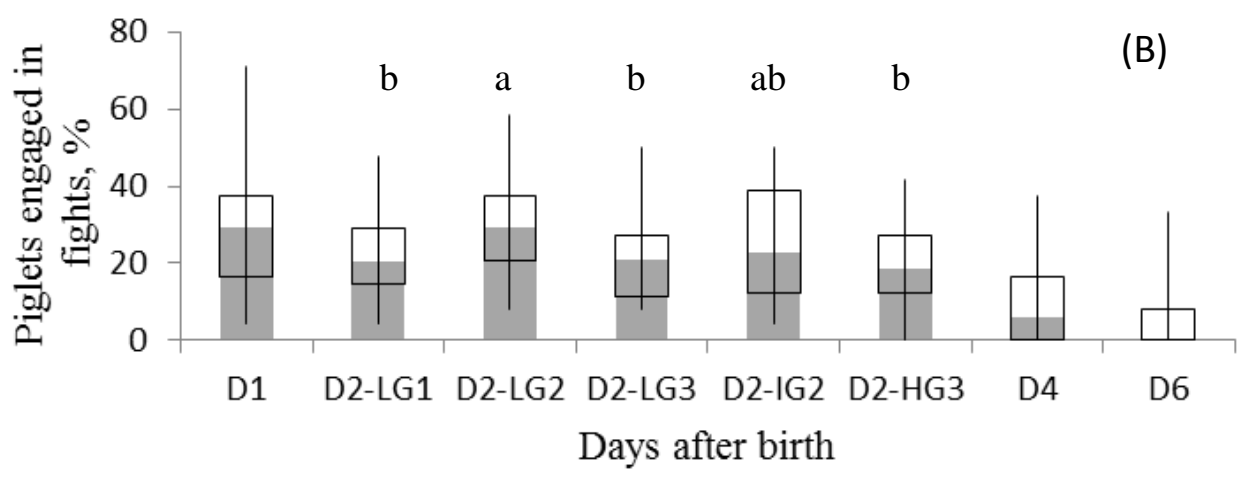

Figure 2. Number of fights (A) per piglet in each nursing and percentage of piglets engaged in fights (B) before milk ejection on several days (D) of direct visual observation in litters composed of piglets with similar or different birth weights. LG1 = 12 low-birth-weight piglets $(0.80-1.25 \mathrm{~kg}) ; \mathrm{LG}=$ six low-birth-weight piglets mixed with intermediate-birth-weight piglets; IG2= six intermediate-birth-weight piglets $(1.40-1.60 \mathrm{~kg})$ mixed with low-birthweight piglets; LG3= six low-birth-weight piglets mixed with high-birth-weight piglets, HG3= six high-birth-weight piglets $(>1.70 \mathrm{~kg})$ mixed with low-birth-weight piglets. Different letters $(\mathrm{a}, \mathrm{b})$ indicate statistical differences among groups of piglets $(\mathrm{P}<0.05)$. No differences were observed on D2, D4 and D6 for the number of fights and on D1, D4 and D6 for the percentage of piglets engaged on fights $(\mathrm{P}>0.05)$. In these cases, overall results are presented. The boxes show minimum, first quartile, third quartile and maximum values. The superior limit of the grey bar represents the value of median. 

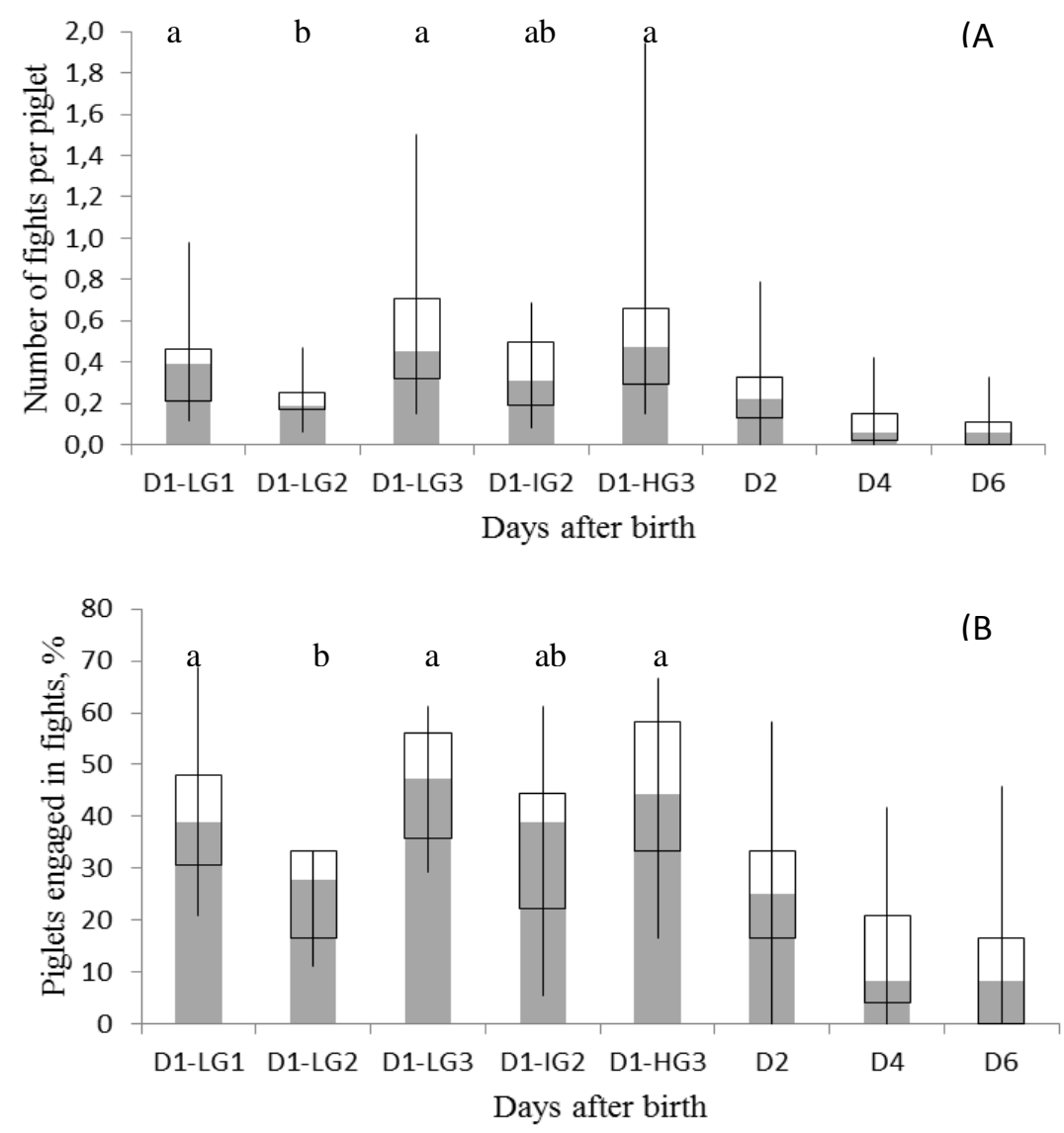

Figure 3. Number of fights (A) per piglet in each nursing and percentage of piglets engaged in fights (B) during 15 min after milk ejection on several days (D) of direct visual observation in litters composed of piglets with similar or different birth weights. LG1 $=12$ low-birth-weight piglets $(0.80-1.25 \mathrm{~kg})$; LG2= six low-birth-weight piglets mixed with intermediate-birth-weight piglets; IG2 $=$ six intermediate-birth-weight piglets $(1.40-1.60 \mathrm{~kg})$ mixed with lowbirth-weight piglets; LG3= six low-birth-weight piglets mixed with high-birth-weight piglets, HG3= six high-birthweight piglets $(>1.70 \mathrm{~kg})$ mixed with low-birth-weight piglets. Different letters $(\mathrm{a}, \mathrm{b})$ indicate statistical differences among groups of piglets on D1 $(\mathrm{P}<0.05)$. No differences were observed on D2, D4 and D6 $(\mathrm{P}>0.05)$ and overall results are presented for these days. The boxes show minimum, first quartile, third quartile and maximum values. The superior limit of the grey bar represents the value of median.

Table 1. Body weight on days (D) 4, 6, 8, 12 and 16 (means \pm SEM) and survival rate of piglets until 16 days of age (minimum - maximum - median) in litters composed of piglets with similar or different birth weights

\begin{tabular}{lccccc}
\hline Variables & LG1 & LG2 & LG3 & IG2 & HG3 \\
\hline Weight - D4, kg & $1.54 \pm 0.02 \mathrm{a}$ & $1.53 \pm 0.03 \mathrm{a}$ & $1.53 \pm 0.02 \mathrm{a}$ & $2.10 \pm 0.02 \mathrm{~b}$ & $2.46 \pm 0.03 \mathrm{c}$ \\
Weight - D8, kg & $2.31 \pm 0.05 \mathrm{a}$ & $2.32 \pm 0.05 \mathrm{a}$ & $2.32 \pm 0.05 \mathrm{a}$ & $3.05 \pm 0.05 \mathrm{~b}$ & $3.48 \pm 0.04 \mathrm{c}$ \\
Weight - D12, kg & $3.23 \pm 0.08 \mathrm{a}$ & $3.21 \pm 0.07 \mathrm{a}$ & $3.22 \pm 0.07 \mathrm{a}$ & $4.13 \pm 0.08 \mathrm{~b}$ & $4.58 \pm 0.08 \mathrm{c}$ \\
Weight - D16, kg & $4.17 \pm 0.12 \mathrm{a}$ & $4.13 \pm 0.10 \mathrm{a}$ & $4.12 \pm 0.10 \mathrm{a}$ & $5.20 \pm 0.10 \mathrm{~b}$ & $5.68 \pm 0.10 \mathrm{~b}$ \\
Survival - D16, \% & $75-100$ & $67-100$ & $67-100$ & $83-100$ & $83-100$ \\
& $(100) \mathrm{a}$ & $(100) \mathrm{abD}$ & $(83) \mathrm{bE}$ & $(100) \mathrm{ac}$ & $(100) \mathrm{c}$ \\
\hline
\end{tabular}

LG1 = 12 low-birth-weight piglets $(0.80-1.25 \mathrm{~kg}) ; \mathrm{LG}=$ six low-birth-weight piglets fostered with intermediatebirth-weight piglets; IG2= six intermediate-birth-weight piglets $(1.40-1.60 \mathrm{~kg})$ fostered with low-birth-weight piglets; LG3= six low-birth-weight piglets fostered with high-birth-weight piglets, HG3= six high-birth-weight piglets $(>1.70 \mathrm{~kg})$ fostered with low-birth-weight piglets.

Different letters indicate statistical difference $(\mathrm{a}, \mathrm{b}, \mathrm{c} ; \mathrm{P}<0.05)$ or tendency of difference $(\mathrm{D}, \mathrm{E} ; \mathrm{P}<0.10)$ among groups of piglets within each observation day. In all groups, weight differed significantly among D4, D8, D12 and D16 evaluations $(\mathrm{P}<0.05)$. 
The increase in the percentage of piglets that went towards the udder after the creep box was opened, as the lactation advances, suggests that fostered piglets became increasingly familiar with their enclosure and gradually recognised their new dam. The fact that a higher percentage of piglets moved towards the udder in litters composed of light and heavy piglets as compared to the other groups probably indicates that heavy piglets were more active and hungrier, waking up and stimulating their light littermates to behave the same way. This assumption is also reinforced by the higher number of nutritive nursing episodes observed during $24 \mathrm{~h}$ in sows suckling litters composed of light and heavy piglets.

If piglets miss any nursing, they will only have a new opportunity of sucking about one hour later. During the first $6 \mathrm{~h}$ after cross-fostering, some piglets wander around the pen and, therefore, miss some nursings (Horrell and Bennett, 1981; Neal and Irvin, 1991; Straw et al., 1998; Robert and Martineau, 2001). The higher percentage of missed nursings by the low-birth-weight piglets fostered with high-birth-weight piglets confirms previous report (Milligan et al., 2001) that light piglets tend to miss more nursings, mainly when mixed with heavy piglets. In litters composed of light and heavy piglets, the number of fights and the engagement in fights were similar regardless of the weight of piglets. The fact that heavy piglets missed less nursings indicates that they probably gained their dispute and were more active to find a teat to suck. In addition, the fact that light piglets fought more after nursing when they were mixed with heavy than with intermediate piglets indicates that a greater difference in birth weight may intensify the disputes within the litter.

The results of the present study confirm that fights decrease with time, both during and after nursing, probably because teat order was gradually established and, therefore, piglets went to their own teats, preventing additional fights. After farrowing, piglets compete for the teats some piglets establish ownership of a particular teat, whereas others may die of hypoglycaemia if they do not have the chance of sucking, or else survive sucking on the remaining teats (De Passillé et al., 1988). Before teat order definition, piglets massage different teats and, if these are busy with other piglets, fights may happen (Hartsock and Graves, 1976).
Sows recognise their litter by olfactory cues, and may become aggressive towards fostered piglets (Algers and Uvnäs-Moberg, 2007). Although all the piglets of the present study were nursed by adoptive dams, no cases of sow aggressiveness were recorded. This may be explained by the fact that the piglets were cross-fostered within $24 \mathrm{~h}$ after farrowing. Sows show little aggression towards fostered piglets if cross-fostering is performed up to $48 \mathrm{~h}$ post-partum (Dellmeier and Friend, 1991; Robert and Martineau, 2001); however, they become more aggressive if piglets are fostered during the entire period of lactation (Horrell and Bennett, 1981).

The observed increase in the number of playful events with time indicates that social interaction among piglets tended to be less aggressive and friendlier. The high number of playful events in intermediate-weight piglets and heavy piglets, on day 2, shows that these piglets established a favourable social interaction with their littermates faster than the light piglets.

\section{CONCLUSIONS}

Low-birth-weight piglets go towards the udder more often when mixed with heavy piglets than when mixed with intermediate piglets, but they miss more nursings. In spite of some behavioural differences, weaning weight of low-birth-weight piglets is not influenced by the weight of their littermates. However, the survival of low-birthweight piglets is compromised if they are crossfostered with heavy piglets rather than with intermediates ones.

\section{REFERENCES}

ALGERS, B.; MADEJ, A.; ROJANASTHIEN, S.; UVNÄS-MOBERG, K. Quantitative relationships between suckling-induced teat stimulation and the release of prolactin, gastrin, somatostatin, insulin, glucagon and VIP in sows. Vet. Res. Commun., v.15, p.395-407, 1991.

ALGERS, B.; UVNÄS-MOBERG, K. Maternal behavior in pigs. Horm. Behav., v.52, p.78-85, 2007.

BAXTER, E.M.; JARVIS, S.; D'EATH, R.B. et al. Investigating the behavioural and physiological indicators of neonatal survival in pigs. Theriogenology, v.69, p.773-783, 2008.

DE PASSILLÉ, A.M.B.; RUSHEN, J.; HARTSOCK, T.G. Ontogeny of teat fidelity in pigs and its relation to competition at suckling. Can. J. Anim. Sci., v.68, p.325-338, 1988. 
DEEN, M.G.H.; BILKEI, G. Cross fostering of lowbirth weight piglets. Livest. Prod. Sci., v.90, p.279284, 2004.

DELLMEIER, G.R.; FRIEND, T.H. Behavior and extensive management of domestic sows (Sus scrofa) and litters. Appl. Anim. Behav. Sci., v.29, p.327-341, 1991.

DONALDSON, T.M.; NEWBERRY, R.C.; SPINKA, M.; CLOUTIER, S. Effects of early play experience on play behaviour of piglets after weaning. Appl. Anim. Behav. Sci., v.79, p.221-231, 2002.

ENGLISH, P.R. Ten basic principles of fostering piglets. Pig Progress., v.4, p.39-41, 1998.

ENGLISH P.R.; WILKINSON V. Management of the sow and litter in late pregnancy and lactation in relation to piglet survival and growth. In: COLE, D.J.A.; FOXCROFT, G.R. (Eds.). Control of Pig Reproduction. London: Butterworth Scientific, 1982 p.479-506.

ERHARD, H.W.; MENDL, M.; ASHLEY, D.D. Individual aggressiveness of pigs can be measured and used to reduce aggression after mixing. Appl. Anim. Behav. Sci., v.54, p.137-151, 1997.

FRASER, D. Behavioural perspectives on piglet survival. J. Reprod. Fertil. Suppl., v.40, p.355-370, 1990.

FRASER, D.; KRAMER, D.L.; PAJOR, E.A.; WEARY, D.M. Conflict and cooperation: Sociobiological, principles and the behaviour of pigs. Appl. Anim. Behav. Sci., v.44, p.139-157, 1995.

FRASER, D.; THOMPSON, B.K.; FERGUSON, D.K.; DARROCH, R.L. The 'teat order' of suckling pigs. III. Relation to competition within litters. J. Agric. Sci. Camb., v.92, p.257-261, 1979.

HARTSOCK, T.G.; GRAVES, H.B. Neonatal behavior and nutrition-related mortality in domestic swine. J. Anim. Sci., v.42, p.235-241, 1976.

HERPIN, P.; DAMON, M.; LE DIVIDICH, J. Development of thermoregulation and neonatal survival in pigs. Livest. Prod. Sci., v.78, p.25-45, 2002.

HORRELL, I.; BENNETT, J. Disruption of teat preferences and retardation of growth following crossfostering of 1-week-old pigs. Anim. Prod., v.33, p.99106, 1981.

KING, R.H.; MULLAN, B.P.; DUNSHEA, F.R.; DOVE, H. The influence of piglet body weight on milk production of sows. Livest. Prod. Sci., v.47, p.169-174, 1997.
MILLIGAN, B.N.; DEWEY, C.E.; DE GRAU, A.F. Neonatal-piglet weight variation and its relation to pre-weaning mortality and weight gain on commercial farms. Prev. Vet. Med., v.56, p.119-127, 2002.

MILLIGAN, B.N.; FRASER, D.; KRAMER, D.L. Birth weight variation in the domestic pig: effects on offspring survival, weight gain and suckling behaviour. Appl. Anim. Behav. Sci., v.73, p.179-191, 2001

NEAL, S.M.; IRVIN, K.M. The effects of crossfostering pigs on survival and growth. J. Anim. Sci., v.69, p.41-46, 1991.

PETERSEN, H.; VESTERGAARD, K. Integration of piglets into social groups of free ranging domestic pigs. Appl. Anim. Behav. Sci., v.23, p.223-236, 1989.

QUINIOU, N.; DAGORN, J.; GAUDRÉ, D. Variation of piglets' birth weight and consequences on subsequent performance. Livest. Prod. Sci., v.78, p.6370, 2002.

ROBERT, S.; MARTINEAU, G.P. Effects of repeated cross-fosterings on preweaning behavior and growth performance of piglets and on maternal behavior of sows. J. Anim. Sci., v.79, p.88-93, 2001.

SAS Institute, 2005: SAS User's Guide, Release 9.1.3. SAS Institute, Cary, NC.

SPINKA, M.; NEWBERRY, R.C.; BEKOFF, M. Mammalian play: training for the unexpected. Quart. Rev. Biol., v.76, p.141-168, 2001.

STRAW, B.E.; BURGI, E.J.; DEWEY, C.E.; DURAN, C.O. Effects of extensive crossfostering on performance of pigs on a farm. J. Am. Vet. Med. Assoc., v.212, p.855-856, 1998.

THOMPSON, B.K.; FRASER, D. Variation in piglet weights: development of within-litter variation over a 5-week lactation and effect of farrowing crate design. Can. J. Anim. Sci., v.66, p.361-372, 1986.

TUCHSCHERER, M.; PUPPE, B.; TUCHSCHERER, A.; TIEMANN, U. Early identification of neonates at risk: traits of newborn piglets with respect to survival. Theriogenology, v.54, p.371-388, 2000.

WATTANAKUL, W.; EDWARDS, S.A.; STEWART, A.H.; ENGLISH, P.R. Effect of familiarity with the environment on the behaviour and performance response of sows and piglets to grouping during lactation. Appl. Anim. Behav. Sci., v.61, p.2539, 1998.

WIEGAND, R.M.; GONYOU, H.W.; CURTIS, S.E. Pen shape and size: effects on pig behaviour and performance. Appl. Anim. Behav. Sci., v.39, p.49-61, 1994

WHATSON, T.S.; BERTRAM, J.M. A comparison of incomplete nursing in the sow in two environments. Anim. Prod., v.30, p.105-114, 1980. 